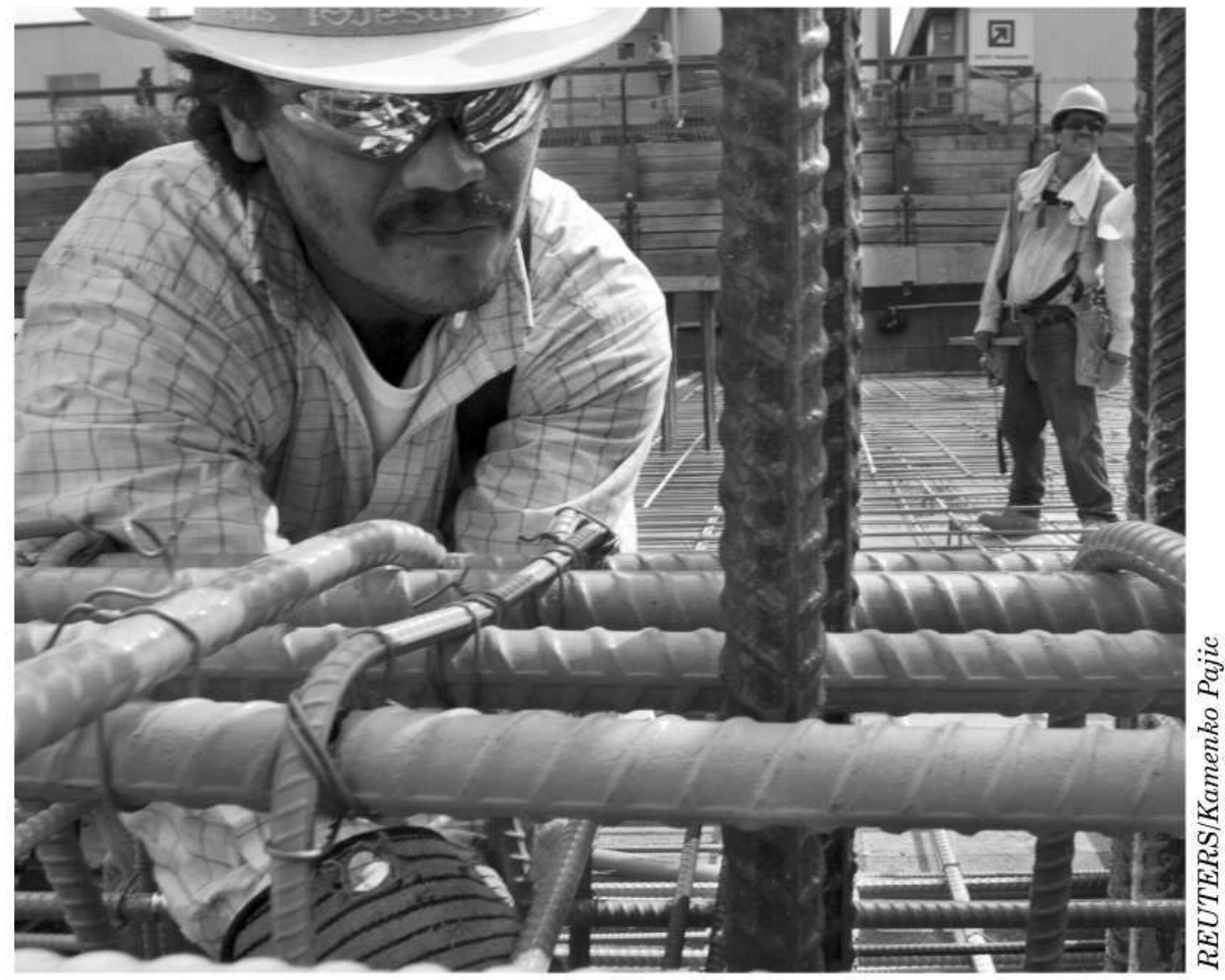

Construction worker at the City Vista development in Washington, D.C., September 8, 2006. City Vista is currently the largest downtown development site in Washington. 
By Jeff Grabelsky

\section{CONSTRUCTION OR DE-CONSTRUCTION? The Road to Revival in the Building Trades}

"BROTHERS AND SISTERS, WE ARE AT A CROSSROADs" ANNOUNCED IBEW PRESIDENT ED Hill to over three hundred thousand union electricians across North America. "There are only two ways we can go. We can continue on with business-asusual and have a front row seat to our own demise, or we can put the IBEW

back on the path of success." That kind of candor may be rare among contemporary labor leaders, but it reflects a perspective held by many building trades unionists who share Hill's view that "we have a hammer over our heads. Call it a crisis. Call it a threat. We could become insignificant in our industry."

According to Peter A. Cockshaw, a national labor analyst who has been covering the construction industry for forty years, "The unionized construction sector is in a battle and a war for economic survival. I have never seen a situation so grave."
The building and construction trades have historically been one of the most stable and secure sectors of the American labor movement. In the period immediately after World War II, their power in the construction industry was legendary, controlling over 80 percent of the work and setting standards that were the envy of workers everywhere. How did the building trades' position devolve so dramatically that it is now commonly described as a crisis of survival? How has the construction industry evolved in ways that have undermined the strength and vitality of building trades unions? 
How have construction unionists responded to the changed circumstances of their industry and their weakened position in it? How has the larger context of a labor movement in crisis influenced the strategic options of building trades leaders on both sides of the national split?

\section{THE CONSTRUCTION CONTEXT: AN INDUSTRY IN TRANSITION}

C ONSTRUCTION IS ONE OF THE MOST IMPORTANT and least understood sectors of the American economy. It is a one trillion dollar industry, a solid barometer of general economic performance, and the only goods-producing sector that continues to post job growth. Between 1994 and 2004, employment grew by 2.5 million-from 5 million to 7.75 million-while mining and manufacturing lost about that many jobs during the same period of time. Over the next decade, construction employment is projected to grow by another seven hundred ninety thousand jobs, lagging behind only retail trade, health care, employment services, and food services. ${ }^{3}$ The opportunity for union growth is enormous.

To some extent, construction has been insulated from the winds of technological and global change that have buffeted other industries. It remains essentially a local industry, bound by geography; buildings erected in Bangladesh cannot be easily transported to Birmingham or Boston. It is still inescapably reliant on craft skills; complex buildings cannot be constructed with unskilled labor. Its workers face the elements, endure cyclical employment, and create wealth with their hands and tools much as their forebears did a century ago.

But the introduction of new technology has partially deskilled the work process and undermined the leverage craft workers once enjoyed. "It used take twenty to thirty minutes to install a set of six-over-six windows," explains Jim Williams, president of the International Union of Painters and Allied Trades (IUPAT). "It required skill to face putty the installation. Today, the windows are fabricated and shipped to the site and it takes just five minutes with light nailing. Now we fight with other trades over the jurisdiction." ${ }^{34}$ Others tell a similar story. "Things were clear-cut a long time ago. We laid brick or set stone," says John Flynn, president of the International Union of Bricklayers and Allied Crafts (BAC). "But now they attach the stone to pre-cast metal panels and ship them to the jobsite. Is that our work or the Iron Workers? These changes cause differences and divisions around jurisdiction, friction and conflict among the trades." Jurisdictional disputes among the crafts have been a constant irritant between building trades unions, and a source of frustration for construction contractors and end-users as well.

One of the significant drivers of change in the industry has been the more active role played by corporate construction users who, beginning in the $1960 \mathrm{~s}$, set out to subvert the "murderous bargaining power" exercised by building trades unions. ${ }^{6}$ Organized into the Construction Users Anti-Inflation Roundtable (later to become the Business Roundtable), major corporations demanded changes in contracting practices, job referrals, and training programs, and deliberately promoted nonunion builders as an alternative to the unionized sector. To a large extent, the Roundtable succeeded; today, open shop contractors control the vast majority of the industry.

While the construction process remains largely bound by geography, both union and 
nonunion contractors rarely confine their operations to a single local market. Rather, the industry is now characterized by increasingly large contractors performing work in regional and national markets. The process of corporate consolidation that occurred throughout the economy during the last decades of the twentieth century transformed construction, as small local contractors were bought up by national companies. This development has posed its own set of strategic challenges to building trades unions, historically structured around local unions functioning in local markets. "Local contractors became regional contractors and regional contractors became national contractors and national contractors became international global contractors," argues LIUNA president Terry O'Sullivan, "but we still have a local collective bargaining mentality." Few local unions have the resources, capacity, or strategic leverage to organize and bargain with the huge contractors that now dominate the industry. A failure to recognize and respond to this reality by deploying regional and national strategies supported by new union structures less deferential to local unions has contributed to the decline of construction unionism. ${ }^{7}$

The participation of multinational building firms-like the Swedish-based Skanska or the German-based Hochtief (through its North American subsidiary, Turner Construction)is not the only or even most significant impact of globalization on the U.S. construction industry. When asked to identify the most important change they have witnessed in the industry, many union leaders respond without hesitation. "The workforce is changing," says Iron Workers president Joe Hunt. "In many states, especially in the Southwest and South, there has been a huge influx of immigrant workers, mostly Hispanic." Global forces have caused the worldwide migration of over 150 million workers, changing the demographics of the
American construction labor force. Latino immigrants, who are now a majority of the workforce in the Southwest, are transforming the industry in other regions as well. "I distinctly remember getting a call from one of our organizers in 1997," recalls Mark Erlich, then the organizing director and now the executive secretary-treasurer of the New England Regional Council of Carpenters. "He said, 'I'm in Andover on a three-hundred unit nonunion jobsite and no one speaks English. What do I do?' That was the beginning. It was during the housing boom, when major national contractors came from the South and other regions with their business and labor practices, including the widespread use of immigrant labor for framing, painting, bricklaying. We had never seen that before." According to Erlich, the immigrant workers were mostly Latinos (especially Mexicans), but also Russians, Irish, and 
Eastern Europeans. "Initially they were transient workers, staying in motels, doing the job, and then leaving. But as the work continued, many decided to stay, to settle in and sink roots in New England communities. They became part of the industry." Unfortunately for the unionized sector, the business practices of the nonunion contractors employing these immigrants-piece rate, cash payments, cutting corners on safety, underage workers on dangerous jobs-have become commonplace in the industry and have unquestionably undermined the standards in residential and light commercial construction. ${ }^{10}$ And, while the increased presence of immigrant workers is driven by global forces beyond the boundaries of the U.S. construction industry, it is also both a cause and consequence of declining standards within the industry.

Even with the influx of immigrants, there are dire predictions of widespread labor shortages in the construction industry. Especially in the South and Southwest, industry experts anticipate inadequate staffing capacities to meet projected demand. According to Engineering News Record, an authoritative industry publication, "The hurricane-shattered Gulf Coast is a Petri dish for construction's national work force crisis. The issues are not new, but their concentration is unprecedented."1

Skilled labor shortages tend to be more common and more severe in regions where the industry has been de-unionized, standards have eroded, and construction is no longer an attractive career choice for new entrants in the job market. "In the past, the building trades have taken tough blue-collar jobs and turned them into good paying, middle-class jobs for people who are bright and ambitious and who don't want to go to college. What's wrong with that?" asks Mark Erlich. "We have taken a body of workers who are treated like dirt in other places where there is no union, and we've given them a good life."'2 But over the last thirty years, the building trades have been marginalized in many areas across the country. "Where you have a major infrastructure project to build or a major building project in a major metropolitan area, we are pretty successful," explains Laborers president O'Sullivan. "But we have little or no presence in other sectors of the industry."13 As a consequence, conditions have deteriorated and wages have fallen dranatically. ${ }^{14}$ In many places, what used to be good career opportunities in construction are now increasingly filled by desperate immigrants vulnerable to exploitation by unscrupulous contractors who drive down the industry's standards. The trend of declining density, market share and standards stings every sector of the building trades.

\section{THE BUILDING AND CONSTRUCTION TRADES: AT A CROSSROADS}

W HILE THE Business Roundtable's antIUNION efforts weakened construction unionism, the more critical contributing factor was the failure of the building trades to organize and bring into membership the rapidly expanding nonunion workforce. According to the BCTD, from 1973 to 2002 , union membership declined from 1.6 to 1.2 million, while the unorganized construction workforce grew from 2.5 to 5.5 million. Consequently, union density declined from 39.5 percent to 17.4 percent during that period of time. ${ }^{\text {Is }}$ That trend has continued as unionization rates have fallen to below 15 percent today. 
In the face of declining density and power, building trades unions have attempted to reorganize their industry's workforce. For example, from 1991 to 2001, the IBEW increased its construction membership by more than eighty-five thousand, but according to veteran organizer

... from 1973 to 2002, [building trades] union membership declined from 1.6 to 1.2 million, while the unorganized construction workforce grew from 2.5 to 5.5 million.

Jim Rudicil, this was not fast enough to meet the labor demands of a rapidly expanding industry. ${ }^{16}$ One of the most notable organizing initiatives was the Building Trades Organizing Project (BTOP), a multiunion, marketwide undertaking in Las Vegas, from 1997 to 1999. But that effort was expensive, yielded mixed results, and soured some construction unionists on multitrade organizing. While Carpenters president Doug McCarron may say "I don't believe BTOP was a failure," most national building trades leaders seem decidedly unenthusiastic about launching similar experiments. ${ }^{17}$ But some construction unionists think that is unfortunate because the dire circumstances of the unionized sector demand precisely the kind of bold thinking that inspired BTOP.

Why would construction unionists resist calls for dramatic action to resolve the crisis of declining density? Some, like Sheet Metal
Workers International Association (SMWIA) president Mike Sullivan, suggest it is a failure of will. "Building trades leaders are ... more concerned about keeping their job than doing the job," says Sullivan. "We're not bold enough because were afraid of what we would lose. The early leaders of the labor movement had nothing to lose, so consequently they were bold enough to take on the fight in a different fashion than we are today, ${ }^{\prime 18}$ For some of today's leaders, there appears to be a contradiction between their diagnosis of the acute problems afflicting construction unionism and the timid nature of their prescriptions for a cure.

Some leaders believe there are internal structural obstacles that must be overcome before the building trades can take back their industry. "Let's look in the mirror . . . and make decisions based on fact not fiction. Let's have more brains than balls and figure things out based on the internal analysis of our respective organizations in the building trades as a whole," implores LIUNA president O'Sullivan. "I think if we did that we would come to the conclusion that we need a complete and total overhaul of our organizational structures." ${ }^{19}$

What are some of the structural obstacles to union revitalization? The tradition of local autonomy makes it difficult for national unions to develop and implement national strategies to organize and bargain with the national contractors that now operate in many local jurisdictions. To the extent multitrade strategies are necessary, and many construction unionists believe they are, the very structure of building trades councils-as voluntary associations lacking the authority to coordinate an organizing 
program in a disciplined way-is also a barrier to union renewal. Another obstacle is the organization of work in the unionized sectors of the Northeast, Midwest, and West which simply does not conform to the reality of open shop construction in the South and Southwest, where traditional craft jurisdictions are generally blurred. "We can't impose the model from Boston or New York on Atlanta or Savannah," explains BCTD president Ed Sullivan. ${ }^{20}$ And, finally, many construction unionists concede that consolidating the fifteen different unions now operating in construction into a handful of better resourced organizations would provide economies of scale and advantages of leverage in reorganizing the industry.

Thus, a combination of inadequate strategies, inappropriate structures, and insufficient will, have limited the success and impact of building trades organizing efforts.

\section{WHAT IS TO BE DONE? PATHS TO UNION RENEWAL}

S EVERAL BUILDING TRADES UNIONS HaVE restructured to facilitate organizing and growth. The Carpenters led the way, creating large regional councils that conformed to the actual structure of construction markets, and that developed sufficient resources and staff to more effectively organize and bargain with regional contractors. For example, in 1996, the six New England states were consolidated into a single regional council that has built an organizing team of forty, increased membership by about 20 percent, and expanded its share of the market from 38 percent to 54 percent. ${ }^{21}$ One of the keys to the council's success is its willing- ness and ability to leverage the power it has in Boston to organize and bargain throughout the region.

\section{... a combination of \\ inadequate strategies, inappropriate structures, and insufficient will, have limited the success and impact of building trades organizing efforts.}

Similarly, the Painters have reorganized its 429 local unions into thirty-five district councils. The union has become more businesslike; the Painters routinely track membership, market share, hours worked and other vital information, and district council leaders are held accountable to implement data-driven strategic plans. Since Jim Williams became president five years ago, the Painters have conducted hundreds of representational elections and increased membership from 102,000 to $127,000^{22}$

Other unions have made structural adjustments as well. The IBEW created a new regional organizing structure and, at its convention in September 2006 , shifted several million additional dollars into programs to grow its membership. In 2004, the Iron Workers chartered a new organizing local, Regional Local 846, that was instrumental in organizing J.D. Steel, one of the largest contractors in the reinforcing steel industry operating throughout the Southwest and employing a mostly immigrant work force. ${ }^{23}$ 
The challenge of organizing has certainly been complicated by the growing numbers of immigrants in the construction industry. The Laborers, Roofers and Painters have made clear their intention to organize all the workers in their jurisdictions, regardless of their immigration status. While Iron Workers president Hunt believes "we can't handle an unending flow of immigrants, he also states unequivocally that his union must organize immigrant workers. "If we can't do that that, our future isn't very bright. If we are going to grow, we have to organize and recruit immigrants, legal or not. We are not going to send 'illegals' back. And, we can't organize immigrants if they are held hostage by their employers." Arguing to draw immigrants out of the shadows of exploitation, Hunt may go farther than other leaders inside and outside of his union when he says: "I don't care if people don't like to use the term, I support amnesty." ${ }^{24}$

The organization of worker centers across the country and the prospect of them someday affiliating with AFL-CIO central bodies raise tricky questions for building trades unions. These centers often serve inmigrants, many of whom work as day laborers in the construction industry and have been ignored or excluded by building trades unions. Will the worker centers devolve into low-wage temporary employment agencies like Labor Ready? Will they evolve into union hiring halls that compete with building trades locals? What are the boundaries between the union hiring halls and day laborer centers? How can the building trades help devise strategies that enable worker centers to thrive by protecting immigrant construction workers while preserving industry standards? Few con- struction unionists have struggled with these questions more thoughtfully than Mike Theriault, secretary-treasurer of the San Francisco Building and Construction Trades Council, who suggests that if worker centers are the "one means of organizing a large number of [day laborers], our ideals say that we should support them when and how we can." Urging fellow building trades unionists to be openminded about worker centers, Theriault says, "The establishment of a tradition of mutual understanding and cooperation among us will serve us all well." ${ }^{25}$

To address the challenge of organizing immigrant workers, the building trades will have to confront their history of exclusion. For many decades, African-Americans were the primary victims of that exclusion. But even white workers in the expanding construction labor market of the post-World War II era were excluded from membership because of a "country club" mentality that continues to infect and impair many building trades locals. The globally driven immigration upsurge demands

\section{To address the challenge of organizing immigrant workers, the building trades will have to confront their history of exclusion.}

renewed scrutiny of union policies that discourage or prevent construction workers from joining the ranks of the building trades.

In a relatively new twist, building trades 
unions are going global in their organizing efforts. For example, Iron Workers organizing director Bernie Evers used the union's relationship with German-based Hochtief to encourage its North American subsidiary, Turner Construction, to persuade J.D. Steele, a Turner subcontractor, to deal more favorably with the union and to eventually sign a collective bargaining agreement. ${ }^{26}$

The Laborers, Sheet Metal Workers, Painters and Iron Workers now participate in international labor bodies like the Building and Woodworkers International and the International Chemical, Engineering and Mining Union in order to wield new forms of leverage in dealing with global contractors.

There are also signs that some building trades unionists are pursuing sectors of the industry or regions of the country that have appeared to be impenetrable to unionization. For example, the IBEW has launched an experimental project to organize the booming construction markets in Florida. The Laborers are contemplating a major residential organizing initiative that may simultaneously target several markets. ${ }^{27}$ The Building and Construction Trades Department has been planning an innovative pilot in the hurricane-ravaged Gulf Coast designed to help meet the anticipated labor demands of regional reconstruction. The project hopes to offer career opportunities to community residents who have been excluded from the trades, demonstrate the efficacy of a high road economic development strategy with good union jobs, begin to build a viable unionized contractor base, and gradually increase Gulf Coast union density beyond its paltry 8 percent levels.

As the industry confronts looming labor shortages, especially in the Gulf Coast region, the gravitational pull of tripartite cooperation among unions, contractors, and end-users has increasingly exerted itself. In an ironic turn, the Business Roundtable-which once conspired to crush the building trades-has now turned to the union sector in the hopes that its superior training capacity might be brought to bear on the problem of skilled labor shortages. In fact, many national building trades leaders believe that skills training available through unionbased apprenticeship programs may be the key to re-establishing the building trades as a dominant force in the industry. ${ }^{28}$ But as important as training may be, it's difficult to see how superior union skills will be enough to out-compete lower cost nonunion contractors that now dominate many markets.

The spirit of cooperation- particularly between unions and signatory employers-has a long history and compelling logic in the building trades. Construction unionists have always been concerned about the economic success of unionized contractors, especially as the competitive pressure from the nonunion sector has intensified. Several unions have recently launched new programs to increase the competitiveness of the union sector by encouraging union members to be more productive and to root out work practices that undermine employer profitability. The first of these was the IBEW's "Code of Excellence," announced by President Hill in a message distributed to the Brotherhood's entire construction membership. Other unions were so impressed that they followed suit. For example, Painter president Williams called on his union to embrace the "Top Workplace Performance Plan" that encourages members to deliver quality work and to abandon costly practices (like extended breaks) that disadvantage signatory contractors. The pro- 
gram requires members with substance abuse problems to avail themselves of union assistance services. Like some other trades, the Painters implemented a three-strikes-and-you're-out policy that would force unproductive and uncooperative members out of the union. One might expect union members to object to these initiatives or to question the logic of expelling members to grow the union. And some certainly did. But Willianns was also inundated with e-mail messages from appreciative members who endorsed the program. One applauded Williams, writing, "I would love to see these people [who can't pass drug tests or adequately contribute to production] replaced permanently by grateful immigrants. ${ }^{2 y}$ It is not yet clear whether these competitiveness strategies can really contribute to union revitalization.

\section{THE AFL-CIO - “CHANGE TO WIN" SPLIT}

T HE STRATEGIC CHALLENGES CONFRONTING CONstruction unionists-stagnant membership, declining density, erosion of bargaining strength and political influence-are certainly not unique to the building trades. The general failure of the labor movement to meet these very challenges precipitated the split that erupted at the July 2005 AFL-CIO convention and the subsequent creation of the Change to Win (CtW) federation. ${ }^{30}$

Two major building trades unionsUnited Brotherhood of Carpenters and Joiners of America (UBCJA) and Laborers International Union of North America (LIUNA)were deeply involved in the AFL-CIO - CtW split. In fact, when Carpenters president McCarron pulled his union out of the AFL-CIO in 2001, over a disagreement concerning organizing and spending policies, the arduous negotiations to persuade him to rejoin the federation contributed to coalescing future $\mathrm{CtW}$ unions into an organized opposition to John Sweeney's leadership. McCarron raised questions and concerns about the federation that helped crystallize the critique of the AFL-CIO eventually expounded by Andy Stern, John Wilhelm, and Bruce Raynor. ${ }^{31}$ In the months leading up to the Chicago convention, national union leaders engaged in a sometimes fierce debate about the future of the labor movement that reverberated through the building trades.

After the Carpenters departed from the federation in 2001, they quietly rejoined the AFL-CIO's Building and Construction Trades Department (BCTD) in 2002. But because their continued membership in a department affiliated with the AFL-CIO was a clear violation of the federation's constitution, their status in the BCTD and its constituent councils around the country remained the subject of constant controversy. Some leaders believe that the lack of a decisive response to the Carpenters complicated efforts to avoid the 2005 split. Ultimately, the Carpenters declined to rejoin the federation and instead joined SEIU, IBT, and others in establishing the rival Change to Win federation. ${ }^{32}$

For a period of time, LIUNA president O'Sullivan managed to keep one foot in each camp. Despite having been a co-founding Change to Win union, the Laborers remained affiliated with the AFL-CIO through the July 2005 convention and many months thereafter. ${ }^{33}$ As an AFL-CIO vice president, O'Sullivan advocated for greater standards and accountability among affiliates. "There should be minimum requirements that we should all be held to. Every affiliated ... union of the federation 
and the building trades should be given time to not only assess whether they have organizing and political capacities, but to build those capacities," he argued. "But there should be a point in time that if you don't have capacities then you should be merged in with somebody else that does." ${ }^{134}$ The demand for higher standards of accountability and the suggestion that smaller unions lacking adequate capacity should be absorbed into larger unions were raised early on in the AFL-CIO debate. Both were contentious propositions-especially among smaller building trades unions-that were never seriously addressed before or after the split.

Six months after the AFL-CIO convention, O'Sullivan pulled LIUNA out of the Building and Construction Trades Department. Joining the Laborers were the Operating Engineers (IUOE). Before departing, both unions had demanded reforms in the department that they suggested would better enable it to "build a movement that ... effectively addresses the construction industry as it is today . . . "35 The reforms would have included changes in the jurisdictional rules that dictate which union members perform what type of work, weighted voting which would have given larger unions a greater voice in department decision-making, and the replacement of the department's officers with an executive director. Some of these reforms were similar to those proposed to the AFL-CIO by CtW unions. While a few BCTD affiliates were receptive to these proposals, negotiators failed to reach an agreement or to prevent LIUNA and IUOE from bolting.

There were some parallels between the negotiations to prevent both the AFL-CIO and
BCTD splits. In each case, dissident unions raised issues of principle like organizational structure, standards of accountability, and the strategic balance between organizing and political activity. In both cases, issues of powerspecifically, who would lead the federation or the building trades department-sometimes

\section{Unfortunately, the discord} in the larger labor movement never really provoked a deep debate within the building trades
about their own future.

seemed to trump these issues of principle. According to those involved in the BCTD negotiations, the ultimate deal-breaker was the demand to preclude current officers from serving in any leadership positions in a restructured department.

On June 1, 2006, despite efforts to persuade O'Sullivan to stay, the Laborers left the federation. Although the Teamsters remained affiliated with the Change to Win federation, they signed a Solidarity Charter with the BCTD in order to participate in department programs. But with the Laborers, Operating Engineers, and Carpenters outside the BCTD, the national labor movement split was now painfully reflected in a fractured building trades.

Unfortunately, the discord in the larger labor movement never really provoked a deep debate within the building trades about their own future. Important questions were not clearly framed nor decisively answered. What 
strategies offer the best chances for revitalizing construction unionism? Which structural impediments to union renewal must be dismantled? Should the fifteen building trades unions be consolidated into fewer, better resourced organizations? How can building trades councils overcome their limitations as voluntary associations and build the capacity to coordinate multitrade organizing campaigns? Grappling with these and other questions might have yielded new strategic insights to guide a resurgence in the building trades.

From their inception, the fundamental source of building trades power has been their "monopolistic" control of the skilled labor supply. Whether today's building trades unions will be able to achieve that control and enjoy that power once again, remains to be seen. There is not yet any strong indication that the unions that left the AFL-CIO and/or joined Change to Win are now any better positioned to reorganize the industry than they were inside the federation. Many leaders believe that the prospects of revitalizing construction unionism are significantly diminished by the split; they hope for a reconciliation that will reunite the building trades. But others have concluded that the building trades-as they are currently constituted-cannot get the job done. They seem determined to chart a new path.

There is reason to believe that a resurgence in construction unionism is possible at this moment in history. The demand for labor will continue to rise as the industry grows and predictions of labor shortages materialize, despite the infusion of immigrant workers. These are not jobs that can be shipped overseas. There is a growing sense of frustration among construction unionists about the inadequacy of their response to the crisis they face, and a growing sense of frustration among unorganized construction workers, especially immigrants, about the conditions to which they are subjected in the nonunion sectors of the industry. There are emerging leaders who are open to innovative strategies to reorganize the industry and still mindful of the lessons to be learned from building trades history. One transcendent truth from the past remains constant and is likely to guide any successful efforts to reunionize construction: building union power requires organizing the industry's workers. In that sense, moving forward may mean that, as Jim Williams says, "It's back to the future."
1. Edwin Hill, State of Our Union, DVD sent to IBEW construction member ship, 2005.

2. Peter A. Cockshaw, State of Our Union.

3. Monthly Labor Review Online, 128, no. 11 (2005): $46-47$

4. Interview with IUPAT president Jim Willtams, September $28,2006$.

5. Interview with IUBAC president John Flynn, September 29, 2006.

6. T. O'Hanlon, "The Unchecked Power of the Building Trades," Fortune, December 1968, p. 102.

7. Interview with LIUNA president Terry O'Sullivan, December 12, 2004.

8. This is especially true among the basic trades including carpenters, painters, laborers, and ironworkers. The impact of immigration is less pronounced among the generally higher skilled, higher paid mechanical trades that include electricians, plumbers, pipefitters, and sheet metal workers.

9. Interview with Iron Workers president Joe Hunt, October 19, 2006.

10. Interview with NERC executive secretary treasurer Mark Erlich, November 3, 2006.

11. Angelle Bergeron, , "Work Force Woes: As the Gulf Coast Fights to Rebuild, Work Force Issues that Plague the Nation are Coming to a Head," Engineering News Record, p. 1.

12. Interview with NERC executive secretary treasurer Mark Erlich, November 3, 2006.

13 Interview with LIUNA president Terry O'Sullivan, December 23, 2004.

14. The Building and Construction Trades Department, AFL-CIO, estimates that between 1973 and 2002 average construction wages have 
dropped by 17 percent

15. Data provided by Building and Construction Trades Department (AFL-C|O). Inside wiremen are employed in the construction industry: outside linemen are employed in the electrical generation and transmission industry. 16. Interview with Jim Rudicil, January 2 , 2007. $1 \mathrm{BE} \mathrm{W}^{\prime} \mathrm{A}$ " membership (inside wiremen and outside linemen) exceeded 320,000 in 2001. Inter view with Carpenters president Doug McCarron, January 11, 2005.

18. Interview with SMWIA president Mike

Sulivan, December 16, 2005. Interview with LIUNA president ${ }^{\prime}$ Sullivan

December 23, 2004.

Inter view with $B C T D$ president Ed Sullivan, November 11, 2004.

. Between 1996 and 2004, membership grew from 20,000 to 25,200. In the Boston area, the New England Regional Council of Carpenters increased its market share from 79 percent to 92 percent, according to NERC executive secretary treasurer Mark Erlich.

22. Interview with IUPAT president Williams, September 28, 2006. U.S. Department of Labor, Employment Standard Administration, Office of Labor Management Standards, Report Form LM$22000-20096$

23. Interview with Iron Workers president Joe Hunt, October 19, 2006

24. Interview with Iron Workers president Joe Hunt, October 19, 2006.

25. Mike Theriault "Building the Trades,"
Organized Labor, November 20, 2006. Theriault is the secretary-treasurer of the S.F. BCTC.

26. Presentation by Bernie Evers, BCTD National Legislative Conference, April 18, 2005

27 Inter view with Change to Win federation campaign director Bob Callahan, October 19 2006.

28. Interview with BAC president Flynn, September 27, 2006. Interview with IUPAT president Williams, September 28, 2006.

29. Inter view with IUPAT president Williams, September 28,2006 . The quoted e-mail message focused specifically on members who repeatedly failed drug tests.

30. Former AFL-CIO affiliates SEIU, IBT, UFCW, UNITE-HERE, and UFWA joined the unaffiliated UBCJA to form the Change to Win federation.

31. Andy Stern is SEIU president; John Wilhelm was HERE president before its merger with UNITE; Bruce Raynor was UNITE president and is now UNITE-HERE president.

32. Construction Labor Report, BNA, March 23, 2005, p. 90.

33. Construction Labor Report, BNA, August 16,2006, p. 791.

34. Interview with Terry O'Sullivan, December 23, 2004

35. O'Sullivan quoted in Chicago Sun-Times, February 15, 2006, p. 73.

36. Inter view with IUPAT president Jim Williams, September 28, 2006. 
1 